\title{
In Vitro Study of Callus Induction in Wedelia trilobata Using Different Growth Regulators
}

\author{
Tripti Thakur, Rakesh Dadsena, S.B. Nandeshwar ${ }^{1}$ \\ and Anil Kumar* \\ Department of Biotechnology \& Zoology, Govt. V.Y.T.P.G. Autonomous College, \\ Durg (C.G.) 491001, India
}

Key words: Wedelia trilobata, Callus induction, In vitro

Wedelia trilobata (L.) Hitch is a member of Asteraceae (formerly Compositae), the sunflower family. Its common name includes "Wedelia" and trailing daisy, although some people mistakenly call it Singapore daisy. In a wider sense the genus Wedelia, named in honor of Georg Wolfgang Wedel (1645-1721), Professor of Botany at Jena, Germany, has about 70 species of tropical strand plant, Wollastonia biflora (formerly known as Wedelia biflora), to which it is closely related. In a more narrow sense, and now more widely accepted, Wedelia is considered to be a genus of relatively a few species of strictly American origin, one of which is Wedelia parviceps Blake, a herbaceous or sub-shrubby weed common in croplands, harvested fields, pasteures and roadside bush in hot climate in central America (Garcia et al. 1975). Interestingly, the Hawaiian endemic genus Lipochaeta is scarcely distinct from it genetically, and two sections of Lipochaeta appears to have been independently derived from Wedelia like ancestors (Wagner et al. 1990).

Growth conditions of plants may impair the reproducibility and significance of a designed experiment. In addition to phytotronic cabinets and exposure chambers supplying the quality, quantity, directions, and temporal variation of the artificial light (Thiel et al. 1996), plant nutrition is important to ensure a defined and reproducible experimental system. Wedelia is only seen at its best in truly tropical climate, where heat and humidity combine to help it produce great sheet of foliage starred with golden daisy flowers. Since Wedelia trilobata is recognized as medicinal plants, which synergistically suppress androgen activity, act as hypoglycemic diterpene etc. A protocol has been undertaken for its micropropagation under controlled laboratory condition.

*Corresponding author. <aimum_aishley@Yahoo.co.in>. '1Central Institute for Cotton Research, Nagpur (Maharashtra), India. 
Healthy young part of leaf, shoot tip and nodal part of Wedelia trilobata were collected from the Botanical garden of the college at Durg, Chhattisgarh, India. The parts of leaf, shoot and nodes (1 to $1.5 \mathrm{~mm}$ ) were excised and then washed thoroughly under running tap water for $30 \mathrm{~min}$ followed by treatment with an aqueous solution of $2 \%(\mathrm{v} / \mathrm{v})$ Teepol (Reckitt Benckiser, India) and $70 \%(\mathrm{v} / \mathrm{v}$ ) ethanol for $15 \mathrm{sec}$ then washed with autoclaved sterile distilled water three to five times. The explants were then surface disinfected with $0.1 \%(\mathrm{w} / \mathrm{v})$ aqueous mercuric chloride solution for $5-6 \mathrm{~min}$ and finally rinsed with autoclaved distilled water (5 - 7 changes). The leaf, shoot and nodal segments were then trimmed at both ends prior to inoculation on culture media.

Five disinfected leaf, shoot, and nodal segments were cultured in each flask separately in MS supplemented with 3\% (w/v) sucrose (Himedia, India) and $0.8 \%$ $(\mathrm{w} / \mathrm{v})$ agar for culture initiation. Ten flasks were used for each experimental set. The $\mathrm{pH}$ of the medium (supplemented with respective growth regulators) was adjusted with $1 \mathrm{~N} \mathrm{NaOH}$ or $1 \mathrm{~N} \mathrm{HCL}$ before addition of $0.8 \%(\mathrm{w} / \mathrm{v})$ agar (Himedia, India). In the experiments, all chemical used were of analytical grade (Himedia, Sigma and Qualigens). The medium was dispensed into culture vessels (Borosil, India) and autoclaved at $105 \mathrm{kpa}\left(121^{\circ} \mathrm{C}\right)$ for $15 \mathrm{~min}$. The surface disinfected explants were implanted vertically on the culture medium (in flask, $250 \mathrm{ml}$ with $25 \mathrm{ml}$ medium) and plugged tightly with sterilized non-absorbent cotton. All the cultures were incubated at $25 \pm 2{ }^{\circ} \mathrm{C}$ under $12 \mathrm{hrs}$ photoperiod of $45-50 \mu \mathrm{mol} / \mathrm{m}^{2} / \mathrm{s}$ irradiance provided by cool white fluorescent tube (Philips, India) and with $55-60 \%$ relative humidity. All cultures with their respective growth regulators were kept in day-to-day observation for the 30 days. Four concentrations of growth regulators were selected for the present study, viz. 2, 4-D (1.5, $2.0 \mathrm{mg} / \mathrm{l})$, 2, 4-D and $\mathrm{Kn} 1.0 \mathrm{mg} / \mathrm{l}$ each and 2, 4-D and $\mathrm{Kn} 2.0$ and 1.0 $\mathrm{mg} / \mathrm{l}$.

The response of 2,4-D $1.5 \mathrm{mg} / \mathrm{l}$ reported after 10, 25 and 30 days, respectively for leaf, shoot and nodal part micropropagation. In leaf explants out of 50 samples in 10 flasks, total success rate $(70 \%)$ for callus formation was reported. In leaf explants callus induction begins from tenth day of inoculation. In shoot tip callusing was reported only in $40 \%$ out of 50 samples from 10 flasks. It was reported after 25 days of inoculation. In nodal explant the success rate of callusing was reported $44 \%$ after $30^{\text {th }}$ day of inoculation.

The response of 2,4-D at $2.0 \mathrm{mg} / \mathrm{l}$ was reported after 7, 10 and 20 days for leaf, shoot and nodal segments, respectively. From leaf explants out of 50 samples in 10 flasks the success rate of callusing was $98 \%$ within 7 days (Fig. 1). From shoot tip it was $54 \%$ explants within 10 days (Fig. 2) and from nodal explant $62 \%$ success rate for callusing was reported within 20 days of inoculation (Fig. 3). 
The response of 2,4-D and Kn with $1.0 \mathrm{mg} / \mathrm{l}$ of each was reported from 15, 15 and 30 days for leaf, shoot tip and nodal parts, respectively. The leaf explants showed callusing in $42 \%$ within 15 days. Similarly, callusing from nodal part was also reported only for $16 \%$ explants within 30 days of inoculation (Table 1 ).

Table 1. Callus formation from leaf, shoot tip, and nodal part of Wedelia trilobata influenced by different growth regulators.

\begin{tabular}{lcccc}
\hline \multicolumn{5}{c}{ Callus formation from leaf } \\
$\begin{array}{l}\text { Growth } \\
\text { regulator } \\
(\mathrm{mg} / \mathrm{l})\end{array}$ & $\begin{array}{c}\text { No. of } \\
\text { explants } \\
\text { inoculated }\end{array}$ & $\begin{array}{c}\text { No. of } \\
\text { explants } \\
\text { responded }\end{array}$ & $\begin{array}{c}\text { Percentage } \\
\text { of } \\
\text { success }\end{array}$ & $\begin{array}{c}\text { Days } \\
\text { of } \\
\text { response }\end{array}$ \\
\hline 2,4-D +Kn $(1.0+1.0)$ & 50 & 21 & 42 & 15 \\
2,4-D + Kn $(2.0+1.0)$ & 50 & 29 & 58 & 7 \\
2,4-D (1.5) & 50 & 35 & 70 & 10 \\
2,4-D (2.0) & 50 & 49 & 98 & 7 \\
2,4-D +Kn $(1.0+1.0)$ & Callus formation from shoot tip & & \\
2,4-D + Kn $(2.0+1.0)$ & 50 & 8 & 16 & 15 \\
2,4-D (1.5) & 50 & 11 & 22 & 10 \\
2,4-D (2.0) & 50 & 20 & 40 & 25 \\
& 50 & 27 & 54 & 10 \\
2,4-D +Kn $(1.0+1.0)$ & Callus formation from nodal part & & \\
2,4-D + Kn $(2.0+1.0)$ & 50 & 8 & 16 & 30 \\
2,4-D (1.5) & 50 & 14 & 28 & 15 \\
2,4-D (2.0) & 50 & 22 & 44 & 30 \\
\hline
\end{tabular}
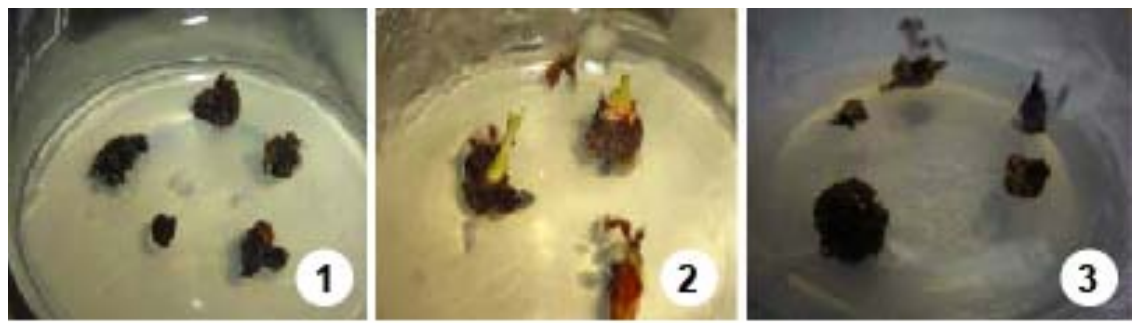

Figs 1-3: 1. Induction of callus from leaf explants. 2. Induction of callus from shoot tip explants. 3. Induction of callus from nodal part.

The response of 2,4-D and $\mathrm{Kn}$ with $2.0 \mathrm{mg} / \mathrm{l}$ and $1 \mathrm{mg} / \mathrm{l}$, respectively was reported from 7, 10 and 15 days of inoculation for leaf, shoot tip and nodal parts, respectively. Callusing from leaf explants was found successful in $42 \%$ within 7 days of inoculation and from shoot tip explants the success rate was only in $16 \%$ within 20 days of inoculation, form nodal part also, the success rate was only $16 \%$ within 15 days of inoculation. 
Best result for callusing (98\%) was reported from leaf explants with 2,4-D (2.0 $\mathrm{mg} / \mathrm{l})$ followed by $70 \%$ with $2,4-\mathrm{D}(1.5 \mathrm{mg} / \mathrm{l})$. For shoot tip explants maximum callusing (54\%) was reported with 2,4-D (1 mg/l) followed by (40\%) with 2,4-D $(1.5 \mathrm{mg} / \mathrm{l})$. Callusing from nodal part was also reported maximum $(62 \%)$ with 2,4-D (2.0 mg/l) followed by $44 \%$ with 2,4-D (1.5 mg/l). In this experiment 2,4-D $(2.0 \mathrm{mg} / \mathrm{l})$ has proved best among all regulators. Among three explants of the plant parts maximum callusing was reported from leaf followed by shoot tip and nodal part (Table 1).

The degree of growth and differentiation varied considerably with the medium constitution (Shekhawat et al. 1993). Besides total nitrogen content, the ratio of nitrate to ammonium $\left(\mathrm{NH}_{4}{ }^{+}\right)$is very important in nitrogen nutrition (Ramage and Williams 2002). This is because the ratio strongly influences the $\mathrm{pH}$ of the medium, which in turn determines the absorption of other nutrients (Tefera and Wannakrairoj 2004). Thus as in most of the plant species, the relatively higher supply of nitrate nitrogen within the MS could have exerted the profound effect on growth of different parts of plants.

Schenk and Hiderbrandt (1972) reported fast growing callus can be obtained with basic medium containing 2,4-D (0.5 mg/l), p-chloro-phenoxy acetic acid (PCPA) (2 mg/l), myo-iniositol ( $1 \mathrm{mg} / \mathrm{l})$ and low levels of $(0.1 \mathrm{mg} / \mathrm{l})$ of $\mathrm{Kn}$. Present experiment also validates the finding of Schenk and Hiderbrandt (1972). Initiation of callus from leaf tissue and their maintenance in suspension culture in LS medium with $(0.3 \%)$ sucrose was reported by Davis et al. (1974). In the present experiment better result in Wedelia trilobata with dextrose (3\%) in MS is reported. Davis et al. (1974) have also reported apparent growth of callus when temperature was raised from 22 to $30^{\circ} \mathrm{C}$. Better result was obtained at $26^{\circ} \mathrm{C}$. Smith et al. (1977) studied induction of callus from different tissue of G. arboretum. They observed that hypocotyls tissue was superior to cotyledons and leaf tissue, but in here better callus induction was observed from leaf explants.

Growth and morphogenesis of plant tissue culture in vitro are largely governed by the composition of the culture medium. Media composition is therefore formulated considering specific requirements of particular culture. For callusing from different parts of Wedelia 2,4-D (2 mg/l) was found best with MS which may proof beneficial for further micropropagation of this plant.

\section{References}

Davis DG, Dusbabek RE and Hoerauf RA (1974) In vitro culture of callus tissues and cell suspension from Okra (Hibiscus esculents L.) and Cotton (Gossypium hirsutum L.). In Vitro Cell Dev. Bio Plant. 6: 365-398.

Garcia JGL, Macbryde B, Molina AR and Macbryde OH (1975) Malezas prevalentes de America Central (Prevalent seeds of Central America). International Plant Protection Center, San Salvador, El Salvador. 
Ramage CM and Williams RR (2002) Mineral nutrition and plant morphogenesis. In Vitro Cell Dev. Bio Plant 38: 116-124.

Smith RH, Price HJ and Thonkton JB (1977) Defined conditions for the initiation and growth of Cotton callus in in vitro G. arbareum. In Vitro Cell Dev. Bio Plant 13: 329334.

Shekhawat NS, Rathore TS, Singh RP, Deora NS and Rao SR (1993) Factors affecting in vitro clonal propagation of Prosopid vinrtis. Plant Growth Reg. 12: 273-280.

Schenk RU and Hildebrandt AC (1972) Medium and technique for induction and growth of monocotyledonous and dicotyledonous plant cell cultures. Can. J. Bot. 50: 199-204.

Theil S, Dohring T, Kofferlien M, Kosak A, Martin P and Seidlitz HK (1996) A phytotron for plant stress research, how for can artificial lighting compare to natural sunlight. J. Plant Physiol. 148: 456- 463.

Tefera W and Wannakrairoj S (2004) Micropropagation of Krawan (Amomum krervanh Pierre ex gagnep). Science Asia. 30: 9-15.

Wagner WL, Herbst DR and Sohmer SH (1990) Manual of the flowering plants of Hawai'i. Vol.1. University of Hawaii Press and Bishop Museum Press, Honolulu. 